\title{
L 310
}

\section{某工場における交代勤務者のストレッサーに関する検討}

\author{
○翼あさみ ${ }^{1}$ 小野雄一郎 ${ }^{2}$ 西谷直子 $^{3}$ 中西栄里 $^{1}$ 安藤群子 $^{4}$ 堀文子 $^{5}$ 加藤保夫 $^{2}$ 大城一 $^{2}$ 大谷直子 $^{2}$ \\ 加藤幸久 ${ }^{2}$ 水野や上い( ${ }^{1}$ 保衛大・衛 ${ }^{2}$ 保衛大・医・公衛 ${ }^{3}$ 東レ愛知 ${ }^{4}$ 名大・医・保健 ${ }^{5}$ 岐皋医療短)
}

【目的】今回、職場のメンタルヘルス対策としての健康教育を企画検傠するにあたって、交代勤務者を含む従業員の ストレッサーの特性を把握するために質問紙調査による検討を行ったので報告する。

【対象と方法】㵶維製造工場の男性従業員 354 名、平均年路 39.6（sd14.8）歳を対象とした。そのうち、交代勤務な し189名、交替勤務あり156名であった。調査方法は仕事上のストレッサーを調べるために開発された質問紙(門倉 ,1997）を含む自記式質問票を用いた。分析方法として人数の少ない 10 歳代と 30 歳代を除いた各年齢階層毎に交代

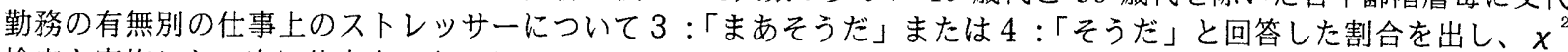
検定を実施した。次に仕事上の各ストレッサーを従属変数とし、交代勤務の有無、年秢、婚姻、通勤時間を独立変数 として重回帰分析を行った。

【結果・考察】 20 歳代・40 歳代・50.歳代の年齢階層別交代勤務の有無別で比較した時、交代勤務有の群においては 訴えが交代勤務なしの群よりも高率であった項目として、20 歳代では「希望していない仕事である」「仕事にやりが いがない」「働きにくい環境である」「自分の意見を取り入れてもらえない」であった。50 歳代では「時間に追われ ている」であった。又、交代勤務有の者において仕事の満足度に関する項目は 20 歳代に比べて年澮とともに訴えが 低下する傾向にあった（表 1 ）。重回州分析において「時間に追われている」「希望していない仕事である」「仕事に やりがいがない」が交代勤務者有で増加する傾向にあり、「仕事がむずかしい」「仕事の要求水準が高い」は交代勤務 有の時に低下する傾向がみられた。(表 2 )。これらから職場における健康支援を企画するにあたっては対象に対して 一律の方法論ではなく、年齢、交代勤務の有無などの特性を考慮したプログラムを㭘討しなければならないと推測さ れる。

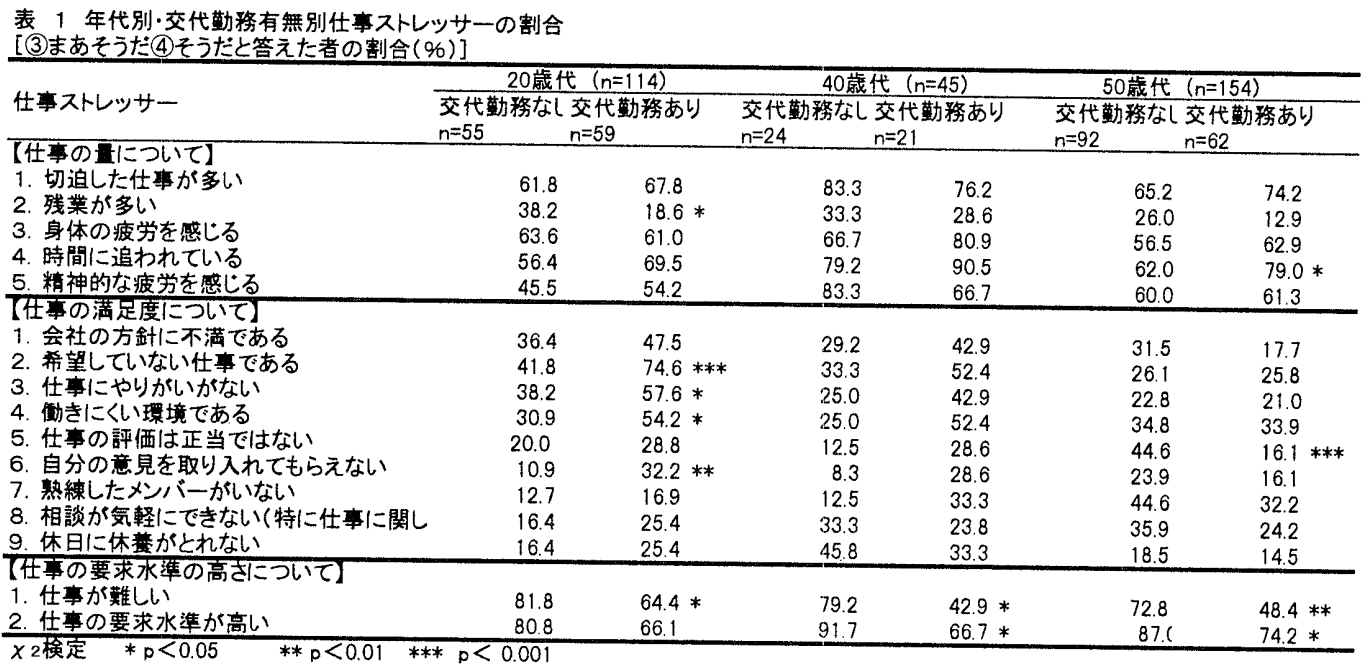

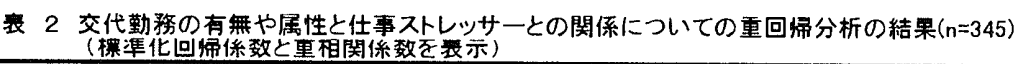

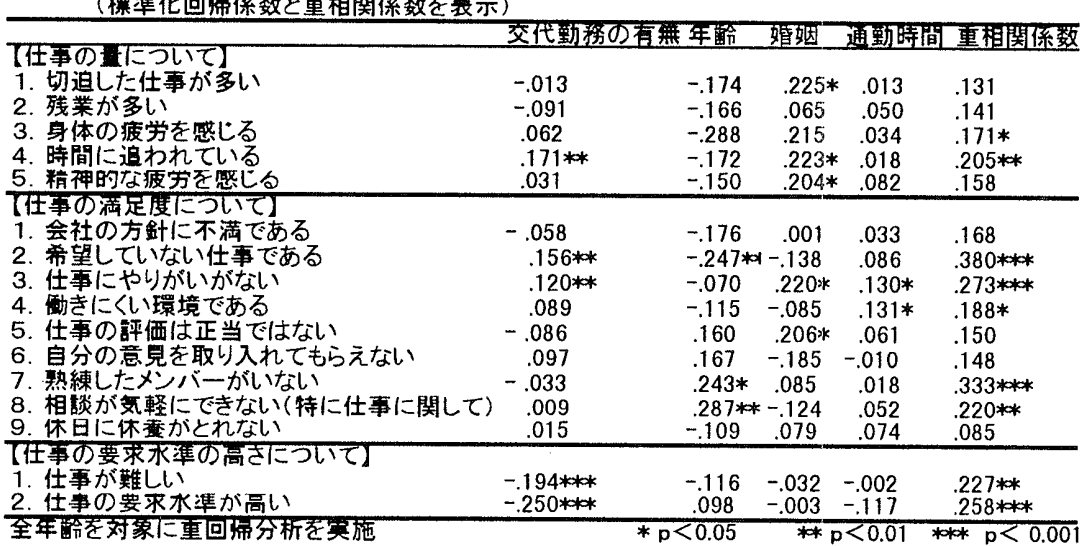

